\title{
The CONCEPT Of empire As A stumbling stone: Aspects of AN ECUMENICAL DISCUSSION ON THE THEME OF EMPIRE
}

Author:

Martina Wasserloos-

Strunk $^{1}$

\section{Affiliation:}

${ }^{1}$ World Alliance of

Reformed Churches,

Geneva, Switzerland

\section{Correspondence to \\ Allan A. Boesak}

e-mail:

mwasserloos@gmx.net

\section{Postal address:}

Postnet Suite 285, Private Bag X15, Somerset West

7130, South Africa

\section{Keywords:}

empire; globalisation;

Accra Declaration;

polarisation; Bible

\section{Dates:}

Received: 21 Aug. 2008

Accepted: 10 June 2009

Published: 06 Nov. 2009

How to cite this article: Wasserloos-Strunk, M., 2009, 'The concept of empire as a stumbling stone: Aspects of an ecumenical discussion on the theme of empire', HTS Teologiese Studies/ Theological Studies 65(1), Art. \#289, 4 pages. DOI: 10.4102/v65i1.289

\section{This article is available} at: http://www.hts.org.za

\section{Note:}

This article was first presented as a paper at a meeting of the Joint Globalization Task

Team of the Reformed Churches of Germany and South Africa, held at Arnoldsheim, Frankfurt, Germany, 26-30 May 2008.

(c) 2009. The Authors. Licensee: OpenJournals Publishing. This work is licensed under the Creative Commons Attribution License.

\section{ABSTRACT}

The topic of empire is one of the main disputed points in the discussion following the 'Accra Declaration'. This article evaluates several points of view from the South and North concerning 'empire' and shows how the dynamics of the different contexts have influenced the tense discussions in the churches. A distinction has to be made between the real-political high profile of modern empires and the more metaphorical interpretation of empire as it is expressed in the Bible. The discussion on empire can become a stumbling block if it is not approached with great compassion for the victims of globalisation, a careful sense of the vastly different situations in the South and the North, and an understanding of real-political structures. This article warns against the danger of polarisation and seeks to build a bridge toward a common understanding.

\section{INTRODUCTION}

Empire has proven to be an unrivalled divisive issue in the church's debate on the Accra Declaration. ${ }^{1}$ This debate does not only have a negative effect. A continuing discussion on the structures of globalisation, the challenges to the church to choose their stance on the matter and the refining of theological categories such as the question of confession have all been positive outcomes. To those can be added a fundamental consideration of the concepts of government, political structures and what is happening in the world.

This discussion is conducted in great detail. I will now give an overview of the debate on empire and will attempt to do so 'gently and precisely', to use the words of the Swiss poet Kurt Marti. To see the world gently and precisely means to look closely while at the same time being aware of one's own blindness. I believe that the discussion on empire has been fairly one-dimensional and has obscured many a global tragedy in a sea of simplifications. The complex, heterogeneous, multilateral structures of our world cannot be systematised under one heading. Yet the image of empire does assist in understanding the world in numerous respects. It helps with the critical analysis of prevalent global coalitions, for example those of economic and security interests. Furthermore the term assists in creating an awareness of the reality of life for many people in the South who find themselves in a state of existential threat. It guides one toward a self-critical consideration of one's own entanglement in power structures that, as the Accra Declaration formulated it, '... put profits above people, do not care for the whole creation and regard as private property the gifts intended by God for all' (par. 25).

Gently and precisely - that is important, because in this matter there is no absolute right or wrong. Even if the participants in all seriousness mutually accuse one another of naivety, lack of proper information, or intellectual superficiality, no one in this discussion is 'right'.

As is so often the case, this discussion is about the 'true doctrine'. It is also about finally tracing all injustice in this world to one address. In this context we find some Cassandras who can paint the devil on the wall with a broad brush and much pleasure.

However, that is only one side of the story. The Northern churches are often assigned (by the South) the role of the naively ignorant or cynical accomplices of empire and are called to 'repentance'. If one speaks of empire in this way, the options for action would then be either submission to empire or martyrdom because of opposition to empire. Both are unacceptable and unhealthy.

Those who like to use the concept 'empire' deduce a causality of consequences: If there is an empire that subordinates all forms of life, that is therefore totalitarian and all-dominating, what necessarily follows is the Christian responsibility to confess, to reject, to anathematise, to sacrifice. If there is idolatry in the market place of the Redeemer and neo-liberalism has become a pseudo-religion, the integrity of the faith is at risk.

The willingness to 'sacrifice' initially finds only a very theoretical expression. Evil is named and its rejection is documented. This changes nothing at all, though theoretically one has taken the side of the victims. If real phenomena are interpreted in supra-real categories, the key to an analysis is lost.

The term 'empire' has featured in ecumenical discussions for some years now. In the Declaration of Buenos Aires in 2003, the representatives of the Southern Reformed Churches stated that the time had come to recognise the present moment as a kairos, calling for decisive action, since the entire creation sees itself confronted with a crisis of life and monstrous suffering.

Though this may sound somewhat exaggerated, one should realise that it is not the experience of the peoples of the South that a socially shaped market economy is fair and that all may profit from it. Their experience is impoverishment, even into the middle class, crime and the loss of social security systems, if these ever existed.

1. Accra 2004, proceedings of the 24th General Council of the World Alliance of Reformed Churches, Accra, Ghana, 20 July-12 August 2004. Published in 2005, World Alliance of Reformed Churches (Geneva), viewed 19 September 2009, from openlibrary.org/b/ OL20146697M. 
This background should be taken into account when the term 'empire' is considered. The Declaration of Buenos Aires formed the basis for the publication of the conference of the World Reformed Alliance in London Colney, UK, which finally challenged the churches of the North to choose their position. This assembly affirmed the concept of empire and challenged especially the North to formulate a confession against the neoliberal economic order.

The Declaration of Colney was later described by the European churches as fundamentalist and as giving a rather simplistic explanation for the multifarious miseries of the world. There were protests against one-sidedness, against unjustified reproaches against the North and against an understanding of confession that was not only unacceptable but also inappropriate. Empire gathers prophets of doom as well as visionaries and utopians and, somewhat less spectacular, those who wish to proceed pragmatically. Sometimes the boundaries are fluid.

Given the countless publications on the theme, the impression is that the discussion has long since taken on a life of its own. It has ceased to be a factual analysis - empire or non-empire. Instead, it is often a case of old scores being settled. Therefore, the impression is that the discussion is not primarily about a model of political order, but rather that at last the dawn of the revolution is shining red upon the barricades of old political fronts. What announces itself as 'visionary' is often nothing but the old criticism of capitalism in new garb, only now significantly enhanced by the demand for a confession. Let it be said quite explicitly, though: Criticism of capitalism is necessary. It protects against hubris and against 'empire'.

Concerning the term 'empire', the church statements in, for instance, the Accra Confession and in the Agape Call of the ninth General Assembly of the World Council of Churches, display a language clearly different from that of scientific political analysis. There is talk of 'the groaning of creation' and 'the cries of the suffering' (Accra), of 'giving confession' and 'transforming love' (Agape). This kind of language does not assist in generating analytical scientific insights. However, that is not what it is meant to do. It is not meant to prove that empire is a political reality, but rather that, for many people, empire is the reality of their lives. That is something totally different.

The empire referred to here is not demonstrable within real boundaries. It does not have a describable political body; rather, it is a metaphor for the fact that many people are delivered into the power of structures over which they have no control. Because it is impossible to adequately describe its totalitarian character, this empire is often explained by means of contradictions: empire versus the Kingdom of God, the empire of Babylon versus the kingly rule of Jesus Christ. It is essentially about good against evil, damnation over and against redemption. Such descriptions are necessary and meaningful in the face of the oppression and hopelessness that people of the South describe as their reality. This living experience should find expression in forceful images, for it consists of existential abandonment and helplessness.

Different levels of communication often sharpen the discussion. When people at ecumenical gatherings report that family members have committed suicide because they were ruined by genetically altered seed from Europe (India and Korea) or when others lament the catastrophic working conditions in the sweat shops of Sri Lanka, and someone else points out that one should also analyse the problem of corruption in Africa, this attitude is felt to be heartless and cold. A reaction to the Accra Declaration and its employment of the concept of empire was published under the title What the World Reformed Alliance could also have resolved. A statement from this document is an example:

All these states (South Korea, Australia, China, India) liberalised their economic order in the direction of market economy mechanisms, some at first unwillingly and only under military pressure from the USA. Out of these and similar developments arose what the WARC decries as "Empire". Indisputably most people can consider themselves fortunate to live in this Empire.

(Lucke 2004, unpublished handout )

Such an observation is deemed cynical and does not contribute to mutual respect. Therefore, the aim cannot be to dispute or analyse away the suffering, the pain, the feeling of abandonment of those people who feel themselves victims of the reality of life. It cannot be to dismiss this truth with an air of intellectual superiority as 'merely felt' but not 'real truth'. Even worse is an attempt to expose these utterances of people in the South as an act of blackmail against the North. Gently and precisely said, it is a picture of a creature exposed and tortured, a picture of wounding and unrestrained power, and a picture of redemption and solidarity, of participation and healing.

In the closing service of the 9th General Assembly of the WCC in Porto Alegre this was sensitively brought to expression, even if the assembly in my view did not take up a real position on empire:

Amid cosmic disorder and the world-wide imperial systems, this is a call, a warning that we may never leave our post as true witnesses of the risen Christ - the living Lord. We shall never have a simple, comfortable relation to empires, but a relation which measures the work of empires by the standard of self-sacrifice given by the cross.

(my translation M.W-S.)

The question is what empire would look like from the perspective of a political reality. Before the fall of communism that was a relatively simple question. There were two empires: one in the East, the Soviet Union, and one in the West, the USA. Each had its assigned evaluation: the one good, the other evil - black and white. Of course in reality neither was only good or only evil, but from the Western perspective there was no doubt as to whom was who.

Contemporary empires show themselves differently. With the decline of colonial imperialism and under the conditions of globalisation an imperialism has developed that is clearly different from that of 'the old days'. New empires are marked by diversified power politics, which in more recent times does not necessarily include aggressive politics of conquest. Whether a power is an empire or not is not to be seen in the conquered square kilometres but in how the power succeeds in applying its power, how power is secured and with whom. (An empire is therefore not simply the United States of America, the European Union or Country X but rather, as the Accra Declaration [section 11] correctly describes, a concentration of power.)

Power is the operative principle of empire. While at least part of the power of the Roman Empire could be shown on the map, today's empires can no longer be described in terms of physical boundaries. Modern empires are made visible by marking the streams of capital, the flow of wares and services, the control of systems of communication and brain drain. The boundaries of modern empires recede, as the political scientist Herfried Münkler (2007:3) puts it, 'into the depths of space'. Empires can only expand their boundaries in a sustainable way if they succeed in overstepping the so-called 'Augustan threshold'.

Münkler has pointed out that an imperial organisation can only survive if it allows those on the periphery to share in the prosperity of the imperial centre. In the case of the empire under discussion, the USA, this means in practice that the continuing military securing of its own interests provokes increasing resistance, mounting costs and rising discontent on the home front' in the long term (Fisch 2005:5). If only for this reason, no empire can survive for long through the accumulation of power and military deployment.

There are centres of power that fulfil these criteria, that pursue a powerful policy of expansion not by conquering foreign lands, 
but by using modern means - a post-imperial imperialism. In this sense China, for example, can be considered an empire.

A recent report of a meeting of 30 African heads of state with the German Federal Ministry for Economic Co-operation and Development shows that the ministry had linked measures advancing development in these countries to conditions: orderly bureaucratic administration, the exclusion of corruption, and the protection of work and the environment. In Kenya, for example, streets were to be built under these conditions. The African heads of state protested vigorously against these unacceptable demands and resolutely left the negotiations. They saw it only as a trade agreement of which the donor states would also benefit.

The streets in Kenya are being built. They are now financed by China without conditions. This also goes for other projects in Africa for which the Chinese donor is generously rewarded with a supply of raw materials. No demands for an orderly bureaucratic administration, the exclusion of corruption and the protection of work and the environment are made by China. This example shows that in the context of real politics there is a different kind of imperial player who secures its power interests with similar ruthlessness as the empires of the past.

Admittedly, the case here is more one of mini-empires rather than one potent empire, which is under ecumenical discussion here. The empire is one. If we visualise two empires side by side the image suddenly loses its appeal. In order to express with this image what it is supposed to express, we must attend to singularity. Beside this empire there are no other idols.

The empire is a priori solitaire; it is also totalitarian in its potency and therefore unique (Arendt 1955:357). The empire divides into good and evil: whoever is not against it is for it; whoever opposes it is good. When thought of in these categories, the metaphor 'empire' in church declarations is one denoting absolute evil. In it, the primal human fear of being devoured has been vividly cast into a word picture (Arendt 2006:112).

Should one associate oneself with such a picture? This categorisation is of little use for tackling the global reality. The actors of the empire are not simply bad and we ourselves good. On the contrary, when we enjoy eating a banana that has been unfairly traded, we ourselves become part of the system.

It may be useful to refer to the 'banality of evil'. Even though evil has a capacity for destruction that makes one shudder, it remains rather superficial, risky, built on crime, lawless and eventually self-destructive. It could fairly easily be done away with by general consensus.

American President Ronald Reagan, by speaking of 'the evil empire' in 1983, introduced this image and made it socially acceptable (8th March 1983 before the National Association of Evangelicals in Orlando, Florida). With that we suddenly find ourselves in a semantic minefield, for though a correct angle remains correct, within it flickers a diffuse mass, an undifferentiated entity, that makes it impossible to adequately describe reality.

Within the ecumenical movement, however, there seems to be a rare agreement about what the term 'empire' encompasses. Empire means that a great power or a coalition of powers, with military support, pursues a policy that secures its own existence often through the radical exploitation of others. The Accra Declaration formulates the nature of empire carefully:

We are aware of the scale and complexity of this situation and wish no simple answers. With our wish for truth and justice and through the eyes of the powerless and the suffering we see that the present world (dis)order is based on an extremely complex and immoral economic system which is defended by an Empire. Under the concept of "Empire" we understand the concentration of economic, cultural, political and military power which constructs a system of rule which is led by powerful nations to protect and defend their own interests.

(Accra Declaration par. 11)

What Accra articulated in a careful and balanced way was subsequently distorted and exaggerated in later 'reworkings' trading under the logo of the World Alliance of Reformed Churches (WARC). What the consultation of the WARC in Manila put on paper under the title "Theological Analysis and Action over against the Global Empire Today' is a case in point. In the Manila paper, against which the Reformed Alliance in Germany and the Protestant Church of the Netherlands (PKN) protested, empire is made responsible for all the misery in the world in such a one-sided and over-simplified way that in the end no remedy seems possible. Neither confession not political action will make a difference. This empire is the end of politics, the end of humanity - reality is parodied in the service of an apocalyptic vision.

One example of how easily the idea of empire can be used to reduce complex political structures to an ideological mishmash is the way in which the participants in the Manila consultation describe the political situation in North Korea:

North Korea's economy, already weakened by the devastations of neo-liberal globalisation, was further driven to the edge by the US trade embargo and economic sanctions....The USA refuses bilateral conversations and normalisation of relations with North Korea. It demonises the land, calls it a part of the "axis of evil" in the hope of forcing a regime change. This has provoked North Korea to strive for nuclear weapons, which in turn increases tensions and drives forward the arms race in North East Asia.

(Manila Declaration 2006)

When perpetrators are turned into victims in this way the victims are misused and denied a sympathetic and careful assessment of their situation. They are victimised again when they are instrumentalised.

What is even worse is that, when a totality that controls everything is thus assumed, then the inability to act is postulated along with it. This merely provides a good feeling of having made a stand and affirmed the truths of faith. It does not constitute genuine civil and social engagement. How then should the conclusion of the Manila paper be put into effect?

This new reality has economic, political, social, cultural, religious and spiritual dimensions. It challenges Christians as a matter of life and death, for the Empire misuses religion to justify its oppressive authority and violence and makes claims that belong to God alone. (An ecumenical faith stance against global empire for a liberated earth community)

Formulations of this kind create the impression of simply escaping real and present political threats and withdrawing into the metaphysical realm, which does nothing at all to encourage realistic discussion and accountability (Theses on Feuerbach, MEW 3, 1990:533). Ecumenical discussion has now produced a caricature of real imperial structures that in fact counteracts every analysis of such power structures that can manifest themselves in the form of actual empires, and thereby implicitly downplays them. ${ }^{2}$

There are in fact such concentrations of power, empires, that ensure their own survival at any cost. There is an increasing scarcity of raw materials and climate change is a fact, both of which are real threats to the world community. Movements for emancipation refrain from thinking this through to its last consequence (Kastner 2002:345). The time has come for civil society to rise up persistently and above all demonstrably. Empire is a challenge to the citizen. When the empire is stripped

2.Similarly assertive: Living faithfully in the midst of empire: Justice, global and ecumenical relations. Unit-Wide Committee, Empire Task Group. 39th General Council 2006. 
of its claims and its eschatological lies, it reveals itself to be an unstable institution, though admittedly with aggressive potential.

To grant empires totalitarian power, to elevate them to the level of evil, in fact protects them from demystification. It exempts them from the pressure of civil society and the balancing effect of democracy.

I have hereby demonstrated that the thoughtless use of the concept of empire in the real context of our society can cause much damage. Even though we may be driven by forces rather than being the driving force, and even if the chance of influencing political reality is slim, civil society and the worldwide ecumenical movement are a power factor that - by public politics, informally, subversively - could penetrate the armourplating of power.

\section{REFERENCES}

Arendt, H., 1955, Frage der Gewaltdisposition von Imperien: Elemente und Ursprünge totaler Herrschaft, Frankfurt, n.p.

Arendt, H., 2006, Über das Böse: Eine Vorlesung zu Fragen der Ethik, München, n.p.

Empire Task Group of the Global and Ecumenical Relations Unit-Wide Committee of the 39th General General-Synod of the Church of Canada, 2006, Living faithfully in the midst of empire, s.l.

Fisch, J., 2005, 'Zu Herfried Münkler: Die Wiederkunft des Imperiums', Neue Zürcher Zeitung, 20 July.
Kastner, H., 2002, Mythos Marktwirtschaft: Die irrationale Herrschaft des Geldes über Arbeit, Menschen und Natur, Bochum, n.p.

Lucke, B., 2005, Was der reformierte Weltbund auch hätte beschließen können, Evangelisch-Reformierte Kirche, Hamburg. (Handout for the synod-discussion about the Accra-Declaration)

Marx, K., Engels F., 1990, Theses on Feuerbach, MEW 3, p. 533.

Möller, U., 2004, 'Folgt im ökumenischen Prozess des Bekennens jetzt die Feststellung des status confessionis? Standortbestimmung vor der Generalversammlung des Reformierten Weltbundes 2004 in Accra', Ökumenische Rundschau 1/2004.

Münkler, H., 2005, 'Neues vom Imperium. Das alte Rom und der 11 September. Reflexionen über politische Ordnungen im Anschluss an Montesquieu', In Die Welt, 12 February 2005.

Rinse-Reeling, B., 2006, 'Die Bedeutung des Empire für die Auslegung der Bibel heute - Einige Bemerkungen zum Buch von Michael Hardt und Antonio Negri', in L. Schottroff et al. (eds.), Das Imperium kehrt zurück - Das Imperium in der Bibel und als Herausforderung für die Ökumene heute, n.p., Wittingen, Erev-Rav.

Stückelberger, C., 2004, 'Klares und differenziertes Bekennen in Accra. Ergebnis der 24. Generalversammlung des Reformierten Weltbundes RWB', Neue Wege, Oktober, p. 12.

WARC Manila Declaration, 2006, 'An ecumenical faith stance against global empire', viewed n.d., from http://warc.ialb. de. 